\title{
Effects of sex, polydactylism and rearing systems on serum biochemical indices of Fulani ecotype chickens in Southwestern Nigeria
}

*Nweke-okorocha, G. O., Chineke, C. A. and Joachim, C. O. Department of Animal production and health, Federal University of Technology, Akure, Ondo State, Nigeria.

Abstract Corresponding author: obynweke@hotmail.com

An experiment was conducted to determine the effects of sex, polydactylism and rearing systems on blood serum biochemical indices of 30 Fulani ecotype chickens selected at random from 90 Fulani ecotype chickens raised under intensive management systems (deep litter and caged) for 16 weeks. Blood samples were collected from the birds at $11^{\text {th }}$ and $16^{\text {th }}$ week was used for biochemical analyses. The parameters measured were Cholesterol, Total protein (TP), albumin (ALB), globulin $(G B)$, aspartate amino transferase (AST), alanine amino transferase (ALT) and alkaline phosphate (ALP). The biochemical parameters were not significantly $(p>0.05)$ different among the sex, polydactyly and rearing systems at 11 weeks but cholesterol in the male birds were significantly $(P<0.05)$ different. Polydactyly was significantly different $(P<0.05)$ for aspartate amino transferase and rearing system were significantly different $(P<0.05)$ for total protein, globulin, albumin and alkaline phosphatase at week 16. The present result is the serum blood parameter of Fulani ecotype chickens which could serve as baseline information for future improvement of Fulani ecotype chickens.

Keywords: Serum biochemical, Sex, Polydactyly, Rearing systems.

\section{Introduction}

Intensive poultry production has been identified as one of the means of attaining sufficiency in the supply of animal protein in the diet of the average Nigerian. Local chicken production predominates the rural areas. High mortality of introduced breeds, low feed resources and lack of understanding of the complex biological and socio economic relationships have limited success of most of the breeding programmes (Ibe, 1998). Local chicken production system deserves to be considered on its merit where small investments can produce good returns. A system that is not only viable but sustainable. Also the positive impact of local chicken production on rural household nutritional status is well recognized (Branckaert, 1996). The predominance of local chicken in Nigerian poultry industry is a good indicator that these chickens deserve more attention for improved performance (Ibe, 1998). An important requirement for this improvement is an appropriate breeding method for bringing about rapid genetic changes. However, major genes of chicken are believed to confer not only adaptability to the tropical climate, but also resistance to diseases (Haunshi et al., 2002). The Fulani eco-type chicken is a native of Fulani tribe in the Middle belt and Northern part of Nigeria. Fulani eco-type chickens have an advantage of being adaptable to our environment and are hardy in nature, tough and resistant to prevailing diseases. Polydactyls are birds that manifest an additional 1 to 2 digits in the foot. Interestingly whilst the feet of some Fulani eco-type chicken display polydactyl, and was having 5 toes, fast growth and heavier 


\section{Effects of sex, polydactylism and rearing systems on serum biochemical indices}

than the non polydactyly. The potential use of biochemical blood parameters as predictors of health status, genetic disease resistant, meat quality and performance characteristics depend on a better understanding of the causes of quantitative variation in these characteristics. This research work was designed to study the effects of sex and polydactism on serum biochemical parameters of Fulani eco-type chicken raised in caged and deep litter rearing system.

\section{Materials and methods \\ Location of the study}

The experiment was carried out at the Poultry Unit of the Teaching and Research Farm of Federal University of Technology, Akure, Nigeria. Akure is situated on $350 \mathrm{~m}$ $(1,150 \mathrm{ft})$ above sea level at Latitude $7^{\circ} 37^{\prime}$ and $7^{\circ} 15^{\prime} \mathrm{N}$ and Longitude $5^{\circ} 11^{\prime} \mathrm{E}$ and $5^{\circ} 31^{\prime}$. The vegetation of the area is that of the Rainforest characterized by hot and humid climate. The mean annual rainfall is about $1500 \mathrm{~m}-2500 \mathrm{~mm}$ and the rain pattern is bimodal with short break in August with average mean annual relative humidity of $75 \%$ to $85 \%$ and average temperature of $27^{\circ} \mathrm{C}$.

\section{Experimental management of birds}

This study was conducted with ninety day old chicks of Fulani eco-type chickens collected from a reputable farm, brooded and managed under intensive care for eight weeks. The birds were sexed and assigned at random into 2 management systems (cage and deep litter) containing mixed sexes and polydactyl of 45 birds each and each treatment was replicated 5 times with 9 birds per replicates in completely randomized design 8 weeks. The birds were fed properly with the best commercial feed from day old to 16 weeks. The birds were given chick starter mash from day old to eight weeks then growers mash from eight weeks to 16 weeks. All necessary medication and vaccines were given to the birds using vaccination schedule for pullet. Fresh water was also provided adequately. Biosecurity was also maintained. At $11^{\text {th }}$ week, thirty (30) Fulani ecotype chickens comprising 15 males and 15 females of polydactyly and non-polydactyly (15 polydactyly and 15 non-polydactyly) were selected at random from 90 Fulani ecotype chickens population raised in both deep litter and caged systems for 16 weeks and were subjected to 12 hours fasting prior to blood collection for serum biochemical parameters. Two $\mathrm{ml}$ of blood were aspirated from the jugular vein using a sterile syringe and needle via wing veins into sterile test tubes without anticoagulant for serum biochemical analyses. Serum was later separated from the blood sample in test tube by centrifugation of the blood samples and were stored with plain purpled top bottle frozen at $-2^{\circ} \mathrm{C}$ prior to analysis. The cholesterol, Total protein (TP), albumin (ALB), globulin (GB), aspartate amino transferase (AST), alanine amino transferase (ALT) and alkaline phosphate (ALP) were determined with a Reflectron ${ }^{\circledR}$ Plus 8C79 (Roche Diagnostic, Gonbh Mahnheim, Germany), using kits. Same process was repeated at 16 weeks for same study. Serum biochemical analysis was carried out twice in this experiment for purpose of comparison at different stages of growth.

\section{Statistical analysis}

Data generated were subjected to least squares means using SAS 9.2 (version 2008) to determine the effects of sex, polydactyl and rearing systems and the interaction between them. Also their level of significance were reported at $(p<0.05)$ and with use of superscripts.

\section{Results}

The serum biochemical parameter of Fulani ecotype chickens is shown in table 1 and 2. 


\section{Nweke-okorocha, Chineke and Joachim}

The least squares means showed that there was no significant difference $(p>0.05)$ between the sex for the biochemical parameters. There was no significant difference $(p>0.05)$ between polydactyly and non-polydactyly for the biochemical parameters. The rearing systems was not significantly different $(p>0.05)$ for the biochemical parameters at the 11 weeks' study while at the 16 weeks' study, the least square means showed that the male Fulani ecotype chickens was significantly different $(p<0.05)$ for cholesterol. There was no significant difference $(p>0.05)$ between polydactyly and non-polydactyly for the biochemical parameters. The rearing systems was significantly different $(p<0.05)$ for total protein, albumin, globulin and alkaline phosphatase (Tables 1 and 2). The male Fulani ecotype chickens recorded higher least squares means for cholesterol $(148.22 \pm 11.34) \quad(167.37 \pm 6.39)$ and Albumin (16.73 \pm 2.51$),(45.10 \pm 2.66)$ respectively at 11 and 16 weeks then for TP (58.53 \pm 2.58$), \quad$ GB $(13.45 \pm 1.01), \quad$ ALT (18.79 \pm 6.56$)$ and ALP $(269.44 \pm 18.93)$ at 16 weeks only while the female sex recorded higher least squares means for globulin (10.46 \pm 1.38$)$, Total protein $(24.28 \pm 2.06)$, aspartate amino transferase (AST) (47.33 \pm 7.99 ), alanine amino transferase (ALT) $(3.55 \pm 1.47)$ and alkaline phosphatase (ALP) $(135.96 \pm 38.85)$ at the 11 weeks and for AST (54.28 \pm 2.45$)$ only at the 16 weeks. The polydactyly recorded higher least squares means for cholesterol (146.62 \pm 13.09), Albumin ( $16.90 \pm 3.35)$ at 11 weeks and for GB (12.70 1.61$)$, TP $(56.70 \pm 3.21)$, A S T $(156.86 \pm 5.83)$ and ALP $(269.44 \pm 20.39)$ at 16 weeks while the nonpolydactyly recorded higher least squares means for globulin $(9.95 \pm 1.84)$, Total protein $(24.23 \pm 2.28)$, AST (39.21 \pm 6.41$)$, $\operatorname{ALT}(2.96 \pm 1.18)$, ALP $(122.39 \pm 33.83)$ at week 11 and for cholesterol (158.48 \pm 7.36$)$, ALB (44.91 \pm 2.30$)$ and ALT (17.50 \pm 5.17$)$ at 16 weeks. The deep litter system recorded higher least squares means for cholesterol $(149.89 \pm 12.15)(160.05 \pm 8.43)$, Albumin $(16.08 \pm 2.52)(47.98 \pm 1.99)$, Total protein $(23.83 \pm 3.70)(62.25 \pm 2.16)$, AST $(42.10 \pm$

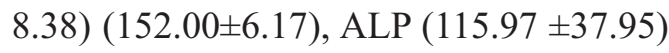
$(294.19 \pm 10.99)$ at week 11 and 16 respectively while the cage system recorded higher least squares means for globulin $(8.80 \pm 2.44)$ at week 16 and ALT $(3.24 \pm 1.46)(18.43 \pm 6.56)$ at 11 and 16 weeks biochemical study (Tables 1 and 2). Means squares for polydactyly revealed significant effect $(\mathrm{p}<0.05)$ for AST, for rearing system for globulin and alkaline phosphate and highly significant effect $(\mathrm{p}<0.001)$ for $\mathrm{TP}$ at 16 weeks The interactions between sex and polydactyly; sex and rearing systems; polydactyl and rearing system; sex, polydactyly and rearing systems were not significant $(p>0.05)$ for the biochemical parameters at week 11 and 16 (Tables 3 and 4). 


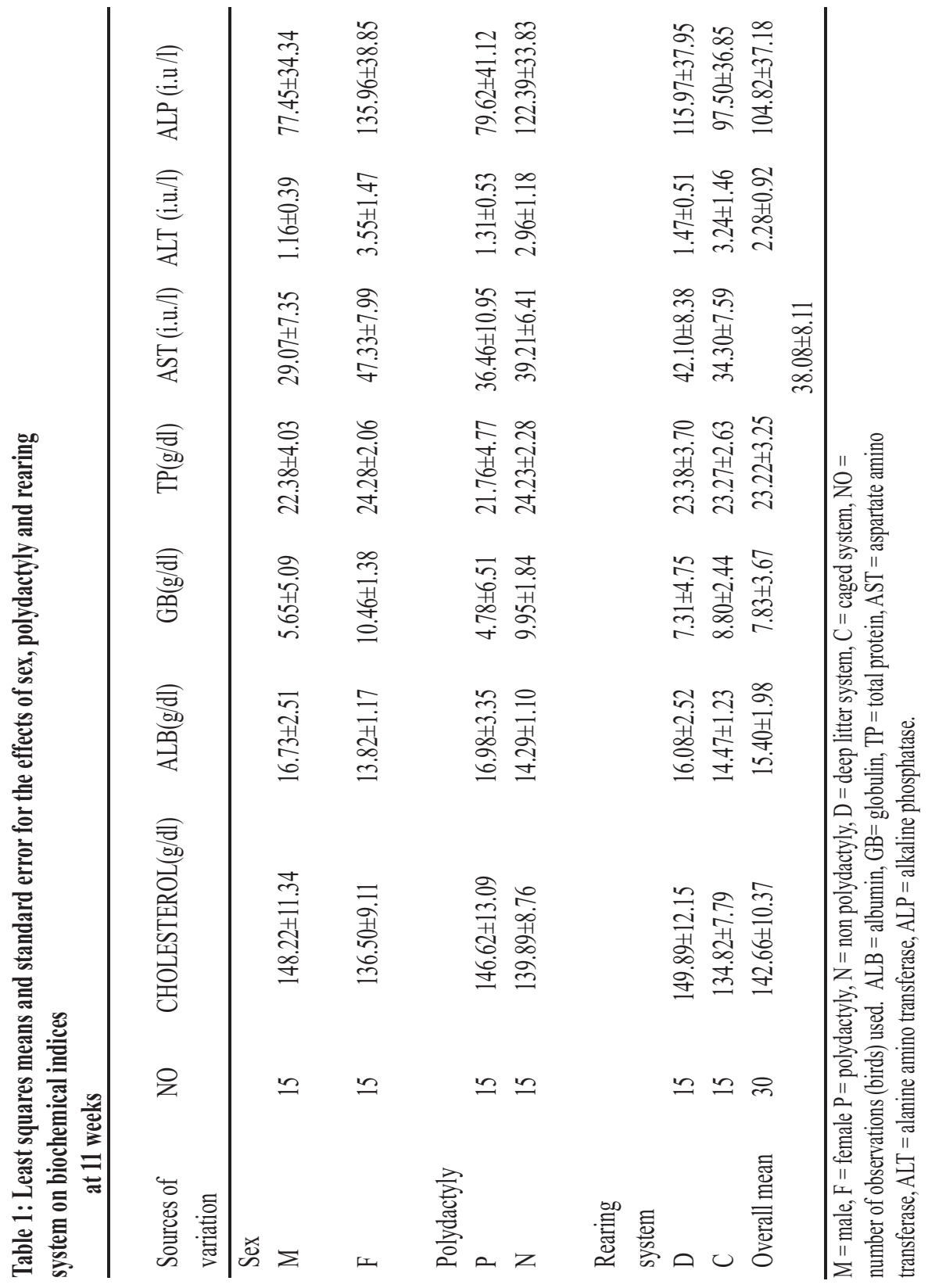




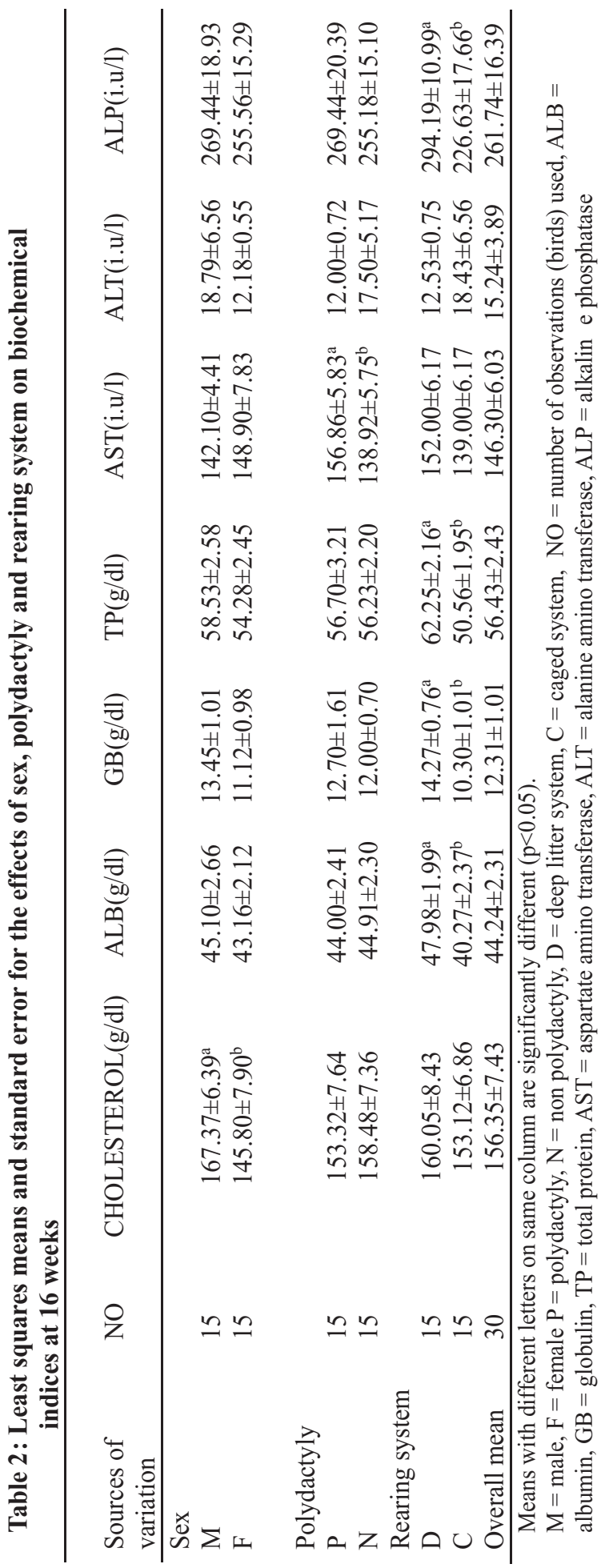


Effects of sex, polydactylism and rearing systems on serum biochemical indices

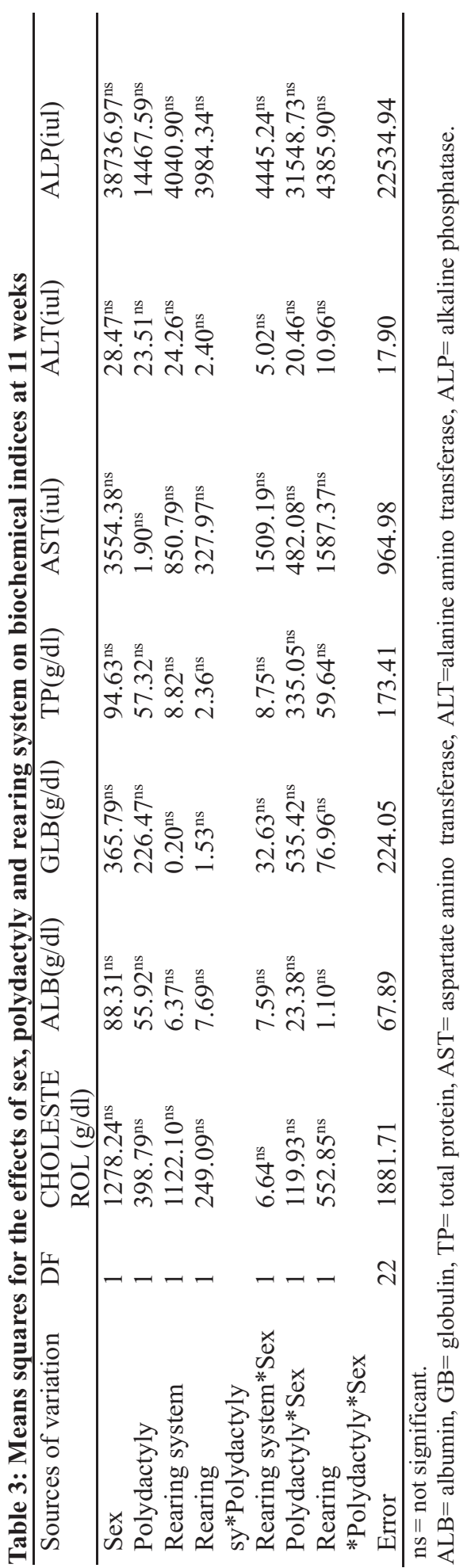


Nweke-okorocha, Chineke and Joachim

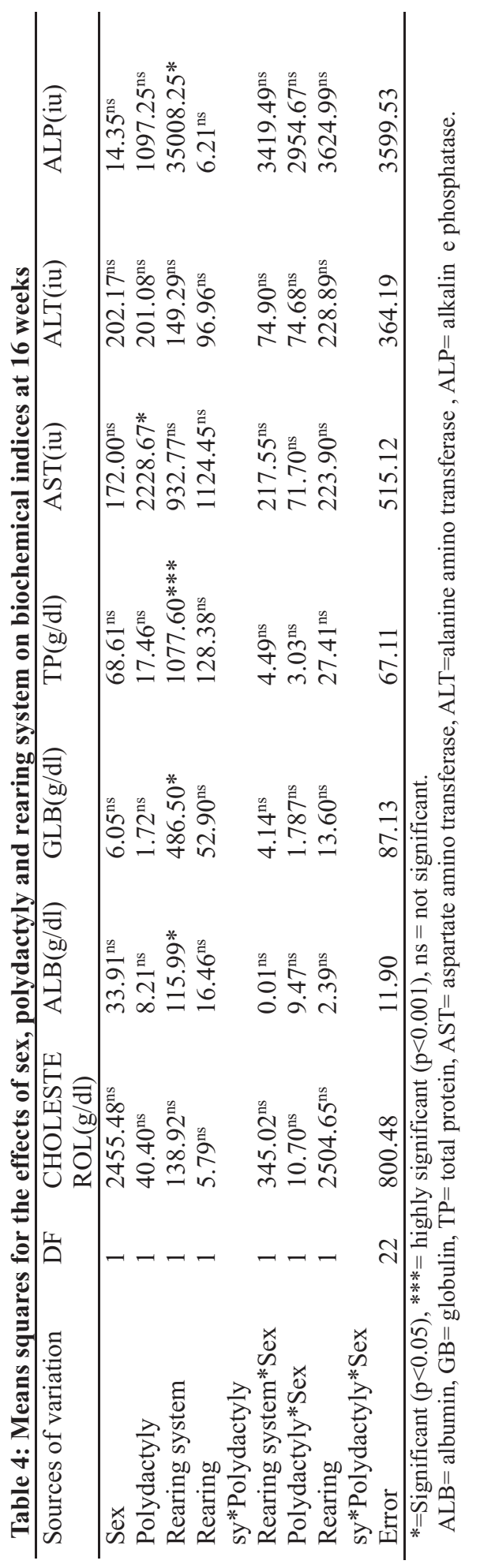




\section{Effects of sex, polydactylism and rearing systems on serum biochemical indices}

\section{Discussion}

The sex, polydactyly and rearing system exerted similarly on the biochemical indices at 11 weeks but differently on cholesterol $(167.37 \pm 6.39 \mathrm{~g} / \mathrm{dl})$ at 16 weeks which agreed with the report by Pampori and Igbal (2007) whose study showed that sex had significant effect on cholesterol in indigenous chickens of Kashmir. The biochemical indices at 11 weeks of this study showed similarity between the sex which agreed with the report of Ladokun et al. (2008). The biochemical indices at week 11 were lower than those obtained at week 16. This could be due to differences in the environmental temperature as at the times the study was carried out as observed in the study by Donkoh (1989) that total protein concentration decreased with the increase in environmental temperature in male broilers. The total protein in Fulani ecotype chickens by sex at 11 and 16 weeks was not different but the female had higher total protein value at week 11 which agreed with the report by Simaraks et al. (2004) and Pampori and Igbal (2007) who studied the serum total protein in broiler and the native chickens of Kashmir respectively. Lisano and Quay (1977) reported higher mean total protein value in female than in male turkeys. Ibrahim et al. (2011) also reported higher values of total protein in their study on effect of sex on serum biochemical parameters in Nigeria indigenous chickens.

\section{Conclusion}

This study revealed the effect of sex, polydactyly and rearing system on serum biochemical indices of Fulani ecotype chickens and could serve as baseline data for improvement of Fulani ecotype and other indigenous chickens.

\section{References}

Branckaert, R. D. S. 1996. From backyard to commercial poultry production. The key to success in village chicken symposium, 6 - 9 December 1995, Pretoria, South Africa. Pg. 11

Donkoh, A. 1989. Ambient temperature: a factor affecting performance and physiological response of broiler chickens. International Journal of Biometeorol. Heidelberg, Germany, 33 (4): 259-265.

Haunshi, S., Sharma, D., Nayal, L. M. S., Singh, D. P. and Singh, R. V. 2002. Effect of naked neck $(\mathrm{Na})$ and frizzle gene (F) on immunecompetence in chickens. International Journal of poultry Science. 43, 28-32.

Ibe, S. N. 1998. Improving productive adaptability of the Nigerian local chicken. Proceedings Sliver Anniversary Conference of Nigeria Society of Animal Production/ West African Society of Animal Production, held 22-26th march 1998 at Federal University of Agriculture, Abeokuta Nigeria. pg. $460-465$.

Ibrahim, A. A., Hassan, A. M., Wada, N. I. and Aliyu, J. 2011. Effect of sex and genotype on blood serum electrolytes and biochemical parameters of Nigerian indigenous chickens. Iranian journal of applied animal science. 2(4) 361365

Ladokun, A. O., Yakubu, A., Otite, J. R., Omeje, J. N., Sokunbi, O. A. and Onyeji, E. 2008. Haematological and biochemical indices of naked neck and normally feathered Nigerian indigenous chickens in a sub humid tropical environment. International Journal of Poultry Science. 7 (1); 55-58.

Lisano, J. and Quay, W. B. 1997. Changes 


\section{Nweke-okorocha, Chineke and Joachim}

in the haematology of turkeys. International Journal of poultry Science. 65, 775-777

Pampori, Z. A. and Iqbal, S. 2007. Haematology, serum chemistry and electro cardiographic evaluation in native chicken of Kashmir. International Journal of Poultry Science. 6; 578-582.
Simaraks, S., Chinrasri, O. and A e n gwa n i c h, W. 2004 . Haematological, electrolyte and serum biochemical values of the Thai indigenous chickens (Gallus domesticus) in northeastern Thailand. Songklanakarin Journal of Science Technology. 26; 425-43.

Received: $14^{\text {th }}$ October, 2019 Accepted: $19^{\text {th }}$ January, 2020 